\title{
Model Penyaluran Beasiswa Terhadap Tingkat Kelulusan Mahasiswa Diploma 3 Manajemen Informatika Stikom Al-Khairiyah Bagi Dunia Kerja Di Kota Cilegon
}

\author{
${ }^{1}$ Didda Rahayu Yuliana., M.Kom, ${ }^{2}$ Teuku Fadjar Shadek., M.Kom \\ I) Jurusan Teknik Informatika, Sekolah Tinggi Ilmu Komputer Al-Khairiyah Cilegon \\ 2) Jurusan Manajemen Informatika, Sekolah Tinggi Ilmu Komputer Al-Khairiyah Cilegon

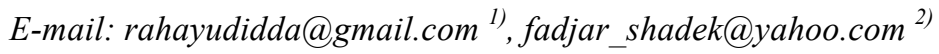

\begin{abstract}
Abstrak - Beasiswa merupakan salah satu alternatif melanjutkan pendidikan bagi mereka yang secara financial masih belum mampu membiayai pendidikan. Sekolah Tinggi Ilmu Komputer Al-Khairiyah merupakan salah satu perguruan tinggi di wilayah Cilegon yang mampu memberikan beasiswa kepada masyarakat kurang mampu dengan program penyaluran beasiswa dari beberapa sumber yang dikelola sejak tahun 2010 melalui Program Studi Manajemen Informatika. Fokus tujuan penelitian ini adalah merumuskan model penyaluran beasiswa dengan capaian bahwa calon mahasiswa yang diberikan beasiswa jumlahnya tetap sama dengan lulusan yang dihasilkan dari program beasiswa tersebut. Model penyaluran beasiswa ini sangat penting bagi kelangsungan program studi manajemen informatika, karena dengan kemampuan yang dimiliki lulusan diploma 3 akan mampu diserap oleh dunia kerja khususnya di Kota Cilegon. Baitul Maal Krakatau Steel Group (BMKSG), Yasayan Madinatul Hadid, Rumah Zakat, Dompet Du'afa, Lazis Uswatun Hasanah, dan Lazis STIKOM AlKhairiyah adalah pemberi beasiswa yang sejak tahun 2010 berperan aktif membiayai mahasiswa di STIKOM AlKhairiyah.
\end{abstract}

Kata Kunci : Model Penyaluran Beasiswa, Mahasiswa Diploma 3, Tingkat Kelulusan, Dunia Kerja

\section{PENDAHULUAN}

1.1 Latar Belakang Masalah

Dalam pembukaan Undang-Undang Dasar tahun 1945 dinyatakan bahwa salah satu tujuan dari kemerdekaan adalah mencerdaskan kehidupan bangsa dan mensejahterakan rakyat. Selain itu juga ada banyak peraturan pemerintah yang menyatakan bahwa pendidikan harus merata dirasakan oleh masyarakat. Berkaitan dengan itu Sekolah Tinggi Ilmu Komputer Al-Khairiyah melalui Tri Dharma Perguruan Tinggi menyalurkan program beasiswa dari para donator seperti Baitul Maal Krakatau Steel Group (BMKSG), Yasayan Madinatul Hadid, Rumah Zakat, Dompet Du'afa, Lazis Uswatun Hasanah, dan Lazis STIKOM Al-Khairiyah. Beasiswa tersebut disalurkan dengan beberapa model pendistribusian. Jumlah Mahasiswa beasiswa setiap tahunnya tidak pernah sama, menyesuaikan dengan kontrak kerjasama yang disepakati oleh pemberi beasiswa dan STIKOM Al-Khairiyah selaku pelaksana program beasiswa.

Tahun 2010 merupakan tahun pertama program beasiswa dilaksanakan oleh STIKOM Al-Khaririyah melalui Prodi Manajemen Informatika dengan jenjang Diploma 3, dari total 193 mahasiswa manajemen informatika ada 147 mahasiswa yang didanai oleh beasiswa. Dan lulusan yang dihasilkan ada 114 lulusan dengan jumlah lulusan beasiswa hanya 96 lulusan. Dari angka tersebut belum bisa diserap oleh dunia kerja secara penuh, karena berbagai factor yang menyebabkan lulusan belum mampu bersaing di dunia kerja khususnya di Kota Cilegon. Salah satu faktonya adalah dalam proses penyaringan calon mahasiswa yang terkesan belum terprogram karena setiap tahunnya proses penyaringan dan pendistribusian beasiswa tidak ditetapkan menggunakan model kerja. Hanya bersifat penyaringan pada salah satu pihak. Sehingga saat pelaksanaan program pendidikan selama 3 tahun atau 6 semester banyak yang mundur tidak sampai selesai menjadi Ahli Madya Manajemen Informatika. Dari 6 pemberi beasiswa hamper $90 \%$ beasiswa diberikan dari Baitul Maal Krakatau Steel Group (BMKSG). Pada tahun 2010 beasiswa mulai direncanakan dan dilaksanakan dengan kerjasama antara STIKOM AlKhairiyah dengan pihak Baitul Maal Krakatau Steel Group (BMKSG). Meskipun tahun 2011 program beasiswa sempat dihentikan namun 2012 program beasiswa kembali dilaksanakan dengan penambahan kerjasama dengan pihak lain seperti Yasayan Madinatul Hadid, Rumah Zakat, Dompet Du'afa, 
Lazis Uswatun Hasanah, dan Lazis STIKOM AlKhairiyah. Kerjasama tersebut berjalan hingga tahun 2016.

Model penyaringan dan penyaluran beasiswa yang selama ini telah berjalan memiliki beberapa kelemahan yaitu mahasiswa yang mendapatkan beasiswa menjadi kurang bertanggung jawab terhadap apa yang didapatkan karena tidak ada ikatan baik dari pemberi beasiswa juga dari pihak STIKOM Al-Khairiyah sehingga mahasiswa terkesan lebih santai dalam proses belajar meskipun tidak melalaikan nilai, karena itu adalah syarat utama untuk mendapatkan beasiswa selain tdak boleh menikah. Selanjutnya adalah kelebihan yang ada pada program penyaringan dan penyaluran beasiswa adalah pemerataan bagi masyarakat kurang mampu yang ingin melanjutkan pendidikan ke jenjang Diploma 3 hanya dengan syarat lulus sekolah menengah atas dan rekomendasi dari kelurahan bahwa calon mahasiswa tersebut benar kurang mampu secara financial. Proses penyaringannyapun hanya dari satu pihak saja. Untuk mengatasi masalah tersebut penelitian ini fokus pada perumusan model penyaluran beasiswa. Proses perumusan model adalah hasil dari analisa kerjasama antara STIKOM Al-Khairiyah dengan pihak pemberi beasiswa dan hasil analisa jumlah mahasiswa beasiswa dengan jumlah lulusan yang tidak pernah sama antara masuk dan lulus. Selain itu juga penellitian ini dilengkapi dengan survey lulusan dan pekerjaan sehingga dari survey tersebut dalam dilihat tingkat lulusan yang bekerja dan yang belum bekerja dari hasil penyaluran beasiswa tersebut.

\subsection{Rumusan Masalah}

Rumusan masalah pada penelitian ini adalah bagaimana merumuskan model penyaluran beasiswa yang efektif pada proses penyaringan dan penyaluran sehingga jumlah lulusan akan sama dengan jumlah pada saat masuk, tentunya tingkat kelulusan tersebut akan mempengaruhi kemampuan lulusan yang akan diserap oleh dunia kerja khususnya Kota Cilegon.

\section{TINJAUAN PUSTAKA}

(2015) The Relevance Of Graduates Of Higher Education In Indonesia With The Requirements Of Labor In The Global Era yang ditulis oleh Titik Handayani Pusat Penelitian Kependudukan LIPI menyatakan bahwa Pasar kerja global yang ditandai dengan terintegrasinya tenaga kerja antar negara juga disertai dengan munculnya ragam - jenis pekerjaan baru seiring dengan inovasi sains-teknologi maupun meningkatnya kreativitas untuk menjawab kompetisi yang semakin ketat. Untuk itu pendidikan tinggi semakin dituntut mampu merespon kebutuhan dunia kerja yang lebih dinamis dan kompleks. Tulisan ini bertujuan mengkaji relevansi lulusan perguruan tinggi di Indonesia dan kebutuhan tenaga kerja di era global. Pendekatan yang digunakan adalah pendekatan kuantitatif menggunakan data sekunder dari berbagai sumber seperti Dirjen Pendidikan TinggiKemendiknas, BPS, ILO dan Bank Dunia serta berbagai hasil kajian yang relevan. Berdasarkan data makro menunjukkan bahwa di Indonesia saat ini terdapat kecenderungan banyak dibuka Perguruan Tinggi (PT) baru secara massif dan lebih berorientasi profit tanpa diikuti dengan penyediaan sarana prasarana yang memadai dan berkualitas, sehingga menghasilkan jumlah lulusan yang terus meningkat. Di sisi lain, kesempatan kerja produktif di Indonesia juga terbatas, sehingga penganggur terdidik relatif tinggi. Persoalan lain, prediksi McKinsey Global Institute (MGI) menunjukkan bahwa dalam pasar kerja global, pada tahun 2030 Indonesia diperkirakan akan mengalami kekurangan tenaga kerja terdidik dan terampil, tetapi kelebihan tenaga kerja non terampil. Adanya kesenjangan antara permintaan dan ketersediaan tenaga kerja berpendidikan juga didukung data ILO (2015) tentang tenaga kerja yang tidak memenuhi kualifikasi pendidikan dan ketrampilan yang proporsinya mencapai lebih dari separuhnya. Adanya permasalahan tersebut semakin mendesak untuk diatasi sejalan dengan pemerlakuan Masyarakat Ekonomi ASEAN maupun berbagai kesepakatan regional lain di tingkat global, karena kurangnya tenaga kerja terdidik dan terampil akan diisi oleh tenaga kerja asing. Dengan demikian kerjasama dan sinergi perguruan tinggi dengan dunia usaha dan dunia industri baik di tingkat nasional maupun internasional perlu ditingkatkan.

(2016) Sistem Alokasi Beasiswa Bidikmisi Pada Perguruan Tinggi Di Lingkungan Kopertis Menggunakan Metode Analytic Network Process yang ditulis oleh Daifiria menuliskan bahwa Beasiswa Bidikmisi adalah program bantuan biaya pendidikan yang diberikan Pemerintah melalui Direktorat Jenderal Pendidikan Tinggi (Dikjen Dikti) Kementerian Nasional mulai tahun 2010. Koordinasi Perguruan Tinggi Swasta (Kopertis) Wilayah-I Sumatera Utara merupakan lembaga yang ditunjuk pemerintah untuk mendistribusikan beasiswa Bidikmisi kepada mahasiswa kurang mampu baik di Perguruan Tinggi Negeri maupun swasta yang berada di kopertis wilayah 1 . Dengan banyaknya PTS yang berada di lingkungan Kopertis Wilayah I Sumatera Utara, maka sulit untuk menentukan PTS mana yang berhak untuk menyalurkan beasiswa Bidikmisi. Selain itu, proses penyeleksian untuk menentukan alokasi jumlah penerima beasiswa Bidikmisi pada masing-masing PTS yang dilakukan secara manual juga belum memberikan hasil yang efisien dan kurang sistematis dan cenderung dapat menimbulkan rasa ketidakadilan dan kecurigaan terhadap Kopertis Wilayah-I Sumatera Utara. Oleh karena itu, penulis membuat sebuah studi yang dapat digunakan untuk mempermudah 
penetapan ranking sebuah Perguruan Tinggi yang akan menerima kuota beasiswa ini dalam jumlah banyak, sedang ataupun sedikit dengan menggunakan sejumlah kriteria. Kriteria yang diguna kan dalam penelitan ini adalah 3 kriteria, 9 sub kriteria dan 5 alternatif. Penilaian dilakukan dengan membagikan kuesioner kepada sejumlah responden. Penelitian ini dilakukan dengan menggunakan metode ANP dan Software Super Decision. Diharapkan dengan penggunaan metode ini, alokasi Perguruan Tinggi penerima beasiswa Bidikmisi di Lingkungan Kopertis wilayah 1 akan tepat sasaran dan proses penyaluran beasiswa menjadi lebih cepat, akurat dan optimal. (2017) Pemilihan Penerima Beasiswa Menggunakan Metode Profile Matching yang ditulis agus junaidi dan vanny visela To help in establishing the determination of students eligible scholarship then needed an analysis relating to anyone students who receive scholarships.One method for analysis of this decision is to use a matching profile. This method was chosen because it can help as a decision supporting the granting of scholarships to students who deserve it. This method also provides information in the form of data which students qualify for scholarships so that motivates their efforts in making the learning process in schools. Research done by the academic aspect of assessment on criteria, aspects of personality, and economic aspects of the family which include the average income a month, dependent parents, and vehicles. After this method is then determined aspects will find the difference (gap) between the profile with the State data from the students and further specified percentage of both aspects and elements together and then do a rank process will determine the optimal alternative, i.e. students who deserve a scholarship. Using profile matching then the process of determining which students will get scholarship can be done quickly and accurately. (2018) Sistem Pendukung Keputusan Untuk Pemberian Beasiswa "Program Jont Degree" Universitas Bhayangkara Surabaya Menggunakan Metode Analytical Hierarchy Process (AHP). Yang ditulis Alek Siswanto, Syariful Alim menemukan bahwa metode analytical hierarchy process memperhitungkan tingkat validitas sampai dengan batas toleransi inkonsistensi berbagai criteria dan alternative yang dipilih oleh pengambil keputusan kriteria yang digunakan adalah nilai IPK, nilai TOEFL, nilai tes TPA dan nilai tes kemampuan komunikasi. Dari hasil percobaan yang dilakukan hasil perhitungan manual dari aplikasi dan perhitungan manual dari pihak lembaga kerjasama mendapatkan presentasi $100 \%$ persamaan dalam menentukan penerima beasiswa. Sehingga menghasilkan perangkingan nilai mahasiswa, dua mahasiswa mendapatka nilai tertinggi di setiap jurusannya yang akan mendapatkan beasiswa program joint gedree

\section{PEMBAHASAN DAN HASIL}

Penelitian dilaksanakan di Sekolah Tinggi Ilmu Komputer Al-Khairiyah Cilegon pada Program Studi Manajemen Informatika dengan jenjang Diploma 3. Populasi penelitian melibatkan seluruh mahasiswa manajemen informatika yang mendapatkan beasiswa dengan jumlah mahasiswa 147 dan jumlah lulusan beasiswa 96 lulusan. Jumlah sampel yang digunakan adalah 42 dari hasil perhitungan menggunakan rumus slovin dengan Margin of error yang ditetapkan adalah $5 \%$ atau 0,05 .

Model yang telah digunakan dalam proses penyaringan dan penyaluran beasiswa masih belum menggunakan prosedur yang tetap sehingga setiap tahunnya ada beberapa perubahan yang masih mengutamakan kebijakan dalam pelaksanaanynya. Model yang telah digunakan ada 2 yaitu :

a. Model Pemberian

Pada penetapan model ini pihak donator yang memberikan rekomendasi calon mahasiswa setelah melakukan penyaringan secara internal dan mentapkan calon mahasiswa untuk di serahkan datanya kepada pihak penyelenggara. Kemudian pihak penyelenggara membuat kontrak kerjasama yang akan disepakati oleh pihak donator dan pihak penyelenggara. Jika kontrak disepakati maka calon mahasiswa yang telah direkomendasikan sebelumnya oleh pihak donator akan menjadi tanggungjawab pihak penyelenggara untuk dididik selama 3 tahun atau 6 semester menempuh diploma 3 pada program studi manajemen informatika sekolah tinggi ilmu computer al-khairiyah cilegon.

Fokus pada model ini adalah mendidik dan memberikan beasiswa kepada yang kurang mampu dalam hal financial, sehingga kedua pihak masih mengutamakan kebijakan pada proses pelaksanaan, dan ini menimbulkan kelemahan pada proses dan hasil pelaksanaan. 


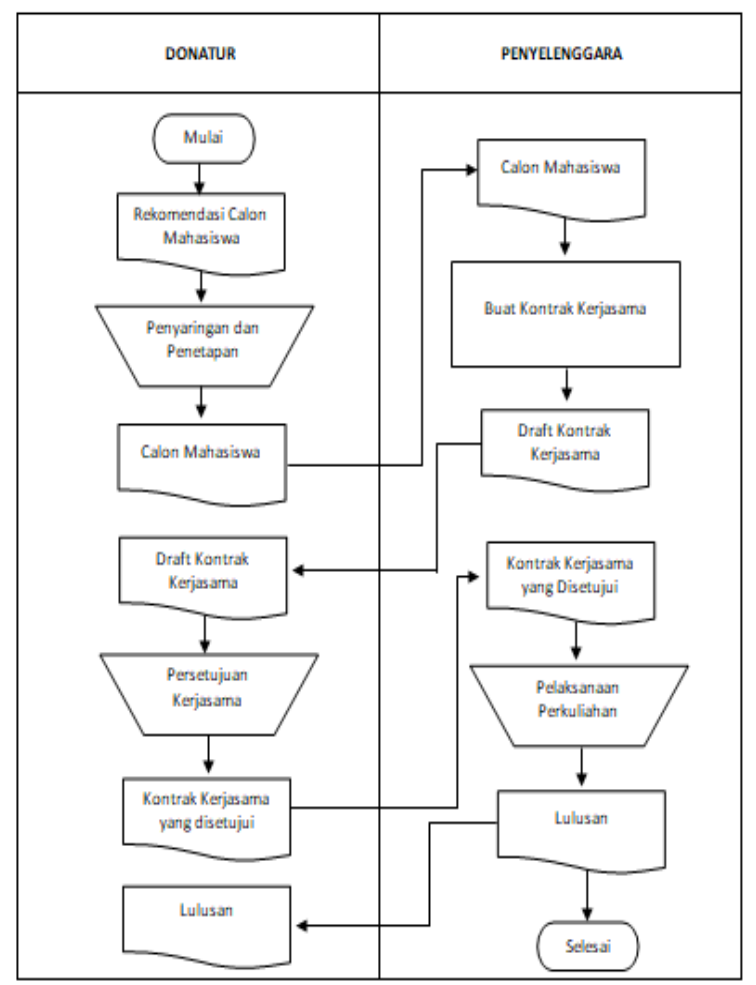

Gambar 3.1 : Model Pemberian

b. Model Pengajuan

Pada model pengajuan ini pihak penyelenggara memiliki rekomendasi calon mahasiswa yang akan diberikan beasiswa sesuai dengan aturan dan prosedur yang telah ditetapkan pada perguruan tinggi khususnya dalam proses penyaringan calon mahasiswa baru. Kemudian mengajukan proposal permohonan kerjasama untuk pembiayaan beasiswa. Proposal akan dibahas oleh pihak donator sebagai pemberi beasiswa dan menetapkan jumlah calon mahasiswa yang akan diberikan beasiswa. Hasil penetapan jumlah dari pihak donator akan dilaksanakan penyeleksian calon mahasiswa oleh pihak penyelenggara. Meskipun pada prosesnya pihak penyelenggara memiliki hak lebih besar dari pihak donator, namun kenyataanya pada saat penetapan calon mahasiswa pihak donatur masih bisa memberikan kebijakan lain pada penetapan tersebut meskipun tidak banyak.

Fokus pada model ini adalah menyeleksi dan mendidik calon mahasiswa, namun karena masih ada kebijakan pada tahap penetapan dari pihak donator maka model inipun memiliki kelemahan.

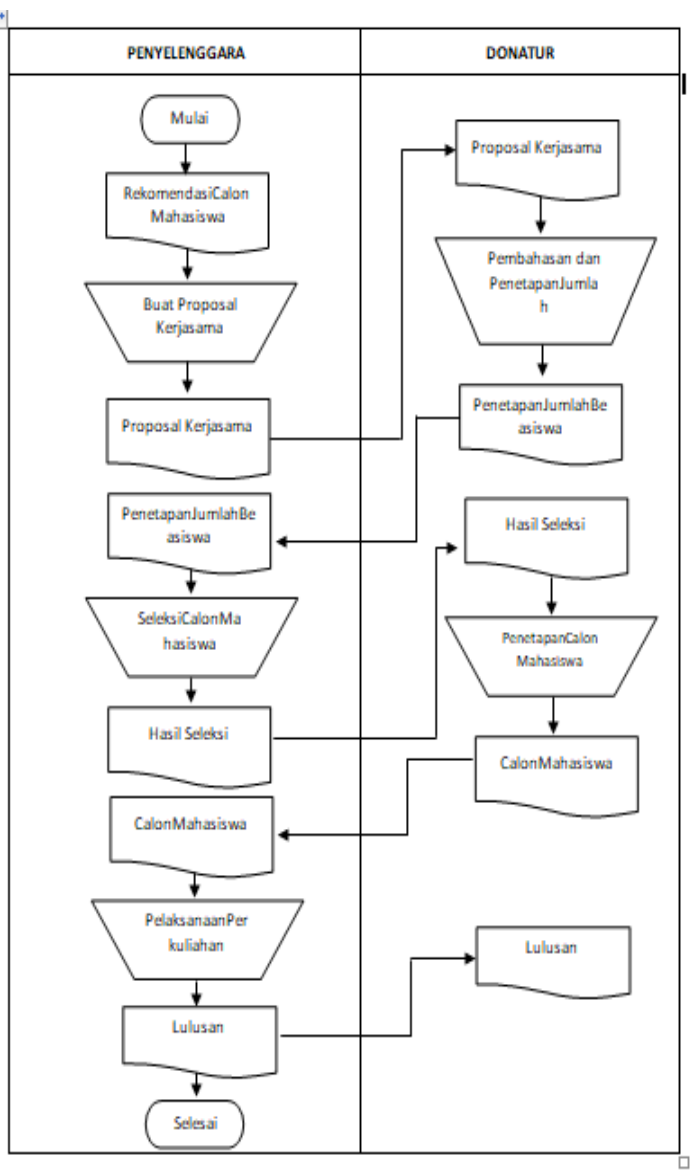

Gambar 3.2 : Model Pengajuan

Dari kedua model tersebut dilakukan analisa data yang menunjukan bahwa beasiswa bukan hanya menjadi tanggungjawab pihak donator ataupun penyelenggara saja, tetapi peran orang tua khususnya calon mahasiswa menjadi sangat penting dalam proses pelaksanaan pendidikan. Banyak bukti yang menunjukan bahwa beasiswa bukan hanya milik mereka yang kurang mampu secara financial tetapi beasiswa tersebut harus diberikan kepada mereka yang siap dan bertanggungjawab mulai dari penyeleksian sampai selesain pelaksanaan. Dengan begitu proses penyaluran beasiswa tidak akan percuma. Berikut ini adalah grafik hasil analisa pelaksanaan program beasiswa menggunakan questioner pada sampel lulusan dari angkatan 2010 sampai 2015.

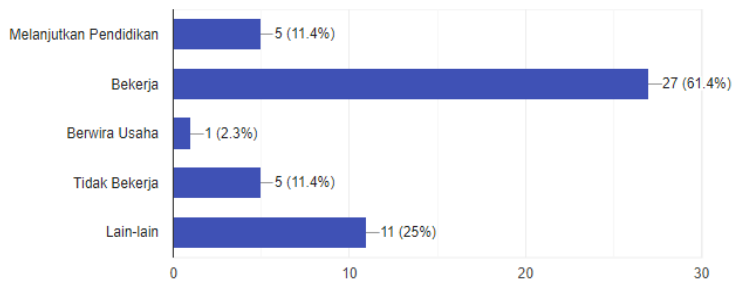

Gambar 3.3 : Grafik Lulusan 
Range yang bisa digunakan pada penelitian ini hanya dari $0-30 \%$ saja dengan hasil bahwa dari jumlah sampel yang digunkaan ada 5 kriteria penetapan bagi status lulusan yang telah mendapakan beasiswa.

a. Melanjutkan Pendidikan

Dari jumlah sampel ada $11.4 \%$ yang melanjutkan pendidikan ke jenjang S1 (Sarjana) di Sekolah Tinggi Ilmu Komputer Al-Khariyah pada program studi Teknik Informatika

b. Bekerja

$61.4 \%$ merupakan angka yang mendominasi untuk lulusan manajemen informatika yang telah bekerja di berbagai bidang di Kota Cilegon. Baik di Perusahaan, Dunia pendidikan maupun di pemerintahan Kota Cilegon.

c. Berwirausaha

Hanya $2.3 \%$ yang memiliki minat pada entrepreneur dari sampel yang ada.

d. Tidak Bekerja

Pada kriteria ini terdapat $11.4 \%$ lulusan yang menjawab tidak bekerja

e. Lain-lain

Untuk kriteria ini ada 25\% lulusan yang memiliki banyak jawaban seperti menikah, ibu rumah tangga, bekerja serabutan, dll.

Hasil analisa yang telah dilakukan menunjukan ketidak tetapan prosedur penyaringan dan penyaluran beasiswa, sehingga berdampak pada proses pendidikan dan jumlah lulusan setiap tahunnya. Untuk itu penelitian ini dilakukan agar dapat merumuskan model baru dalam proses penyaringan dan penyaluran beasiswa. Sehingga akan mengurangi kelemahan yang selama ini dihadapi baik oleh pihak donator maupun pihak penyelenggara pendidikan. Rumusan yang baru akan lebih memfokuskan pada proses pelaksanaan pendidikan yang tidak lagi mengutamakan kebijakan dari kedua pihak dan tentunya melibatkan calon mahasiswa menjadi entitas yang harus muncul pada prosedur kerjasama. Calon mahasiswa diberi kewenangan untuk menerima dan menolak beasiswa yang akan diberika oleh pihak donator, Sehingga pada rancangan model baru ini baik pihak penyelenggara, pihak donator dan calon mahasiswa bertanggungjawab penuh pada prosesnya mulai dari awal sampai akhir.

Selain itu pada prosesnya ada pelaksanaan monitoring yang dilakukan oleh pihak penyelenggara dan memberikan laporan dari hasil setiap monitoring yang dilakukan kepada pihak donator dan juga kepada mahasiswa sebagai evaluasi sehingga pelaksanaan pendidikan dapat dikontrol dengan baik.



Gambar 3.4 : Rancangan Model Baru Penyaringan dan Penyaluran Beasiswa

\section{KESIMPULAN}

Hasil penelitian yang dilakukan menyimpulkan beberapa hal, yaitu :

a. Secara umum prosedur penyaringan dan penyaluran beasiswa yang telah dilaksanakan sejak tahun 2010 dapat dikategorikan efektif dan positif. Namun belum mencapai target yang ditetapkan yaitu lulusan sesuai dengan jumlah mahasiswa yang masuk. Juga dalam proses pelaksanaan pendidikannya mahasiswa dapat bertanggungjawab dengan amanah yang diberikan, sehingga lulusan Sekolah Tinggi Ilmu Komuter Al-Khairiyah khususnya Ahli Madya Manajemen Informatika bermanfaat bagi dunia kerja di Kota Cilegon.

b. Berdasarkan olah data melalui quesioner yang dilakukan pada sampel yang ada, $61.4 \%$ lulusan manajemen informatika yang mendapatkan beasiswa dari tahun 2010 sampai 2015 dengan menggunakan dua model ditetapkan telah bekerja si Kota Cilegon sesuai dengan bidang keahlian yang didapatkan. 
c. Rancangan model baru harus ditetapkan untuk pelaksanaan penyeringan dan penyaluran beasiswa tahun berikutnya sebagai perbaikan dan pengembangan program. Agar kedepannya program beasiswa dapat lebih banyak dirasakan manfaatnya oleh banyak orang, tentunya dengan terlebih dahulu menetapkan model tersebut menjadi peraturan yang harus disepakati bersama melalui kontrak kerjasama bukan kebijakan.

\section{Ucapan Terima Kasih}

Ucapan terimakasih yang mendalam penulis haturkan kepada Kementrian Riset, Teknologi, dan Pendidikan Tinggi. Direktorat Jendral Penguatan Riset dan Pengembangan Direktorat Riset dan Pengabdian Masyarakat yang telah mendanai penelitian ini pada program hibah Penelitian Dosen Pemula Tahun Pelaksanaan 2019. Juga kepada Lembaga Penelitian Pengabdian Kepada Masyarakat Universitas Serang Raya yang telah memfasilitasi penulis dalam mempublish luaran melalui Jurnal PROTEKINFO.

\section{PUSTAKA}

CCSR. 2017. Program Kerja Cilegon Corporate Social Responsibility, Kota Cilegon : CCSR Koentjaraningrat, 1981. Masyarakat dan Kebudayaan, Jakarta: UI Press

Makmur, Syarif. 2007. Pemberdayaan Sumber Daya Manusia dan Efektivitas Organisasi. Jakarta: PT. RajaGrafindo Persada
Malhotra. 2005. Metode Penelitian Sosial, Jakarta: Rineka Cipta

McKenna, Eugene dan Beech, Nic. 2000. The Essence of Manajemen Sumber daya Manusia. Yogyakarta: Andi.

Sarwono, J., 2009. Statistik Itu Mudah Panduan Lengkap Untuk Belajar Komputasi Statistik Menggunakan SPSS 16. Penerbit Andi. Yogyakarta.

Sugiyono, 2009. Metode Penelitian Kuantitatif Kualitatif dan R\&D. Bandung : Alfabeta

Sugiyono. 2006. Memahami Penelitian Kualitatif. Bandung : Alfabeta

Sugiyono. 2007. Statistika untuk Penelitian. Bandung : Alfabet.

V. Wiratna Sujarweni, 2008. Belajar Mudah SPSS untuk Penelitian, Global Media Informasi.

Widodo, T, 2008, Metode Penelitian Kuantitatif, Sebelas Maret University Press, Surakarta

Yulianie, Sri Budi Cantika. 2005. Manajemen Sumber Daya Manusia. Cetakan Pertama: Malang: UMM Press. 